\title{
Change in Heavy Metals Concentrations in Sediments Deposited in Retention Tanks in a Stream after a Flood
}

\author{
Nicole Nawrot*, Karolina Matej-Łukowicz, Ewa Wojciechowska
}

Faculty of Civil and Environmental Engineering, Gdansk University of Technology, Gdańsk, Poland

Received: 12 October 2017

Accepted: 2 January 2018

\begin{abstract}
Our paper presents the results of heavy metal $(\mathrm{HM})(\mathrm{Zn}, \mathrm{Cu}, \mathrm{Pb}, \mathrm{Cd})$ content in bottom sediments from retention tanks along Oliwa Stream in Gdańsk, Poland, before a flood (BF) and after a flood (AF) 14-15 July 2016. The flood had a huge impact on the quality of bottom sediments and their displacement. The concentrations of HM differed significantly for research series conducted 3 months $\mathrm{BF}$ and 8 months AF. The concentration of $\mathrm{Cu}$ increased from $3.5 \mathrm{mg} / \mathrm{kg}$ to $88.8 \mathrm{mg} / \mathrm{kg} \mathrm{BF}$ and from $12.1 \mathrm{mg} / \mathrm{kg}$ to $1,114.3 \mathrm{mg} / \mathrm{kg} \mathrm{AF}, \mathrm{Zn}$ from $27.4 \mathrm{mg} / \mathrm{kg}$ to $129.9 \mathrm{mg} / \mathrm{kg} \mathrm{BF}$; and $42.3 \mathrm{mg} / \mathrm{kg}$ to $244.8 \mathrm{mg} / \mathrm{kg} \mathrm{AF}$, Cd from $0.04 \mathrm{mg} / \mathrm{kg}$ to $0.47 \mathrm{mg} / \mathrm{kg} \mathrm{BF}$, and $0.08 \mathrm{mg} / \mathrm{kg}$ to $0.47 \mathrm{mg} / \mathrm{kg} \mathrm{AF}$. Also, the migration of some metals, mostly $\mathrm{Cu}$ to retention tanks located downstream, was observed, resulting from the washing away of sediments in the upper part of the stream. Since the stream inflows to the Gulf of Gdansk, urban flooding created a risk of migration of contaminants to the Baltic Sea.
\end{abstract}

Keywords: contamination; heavy metals; sediments; urban flood; copper

\section{Introduction}

The source of stormwater pollution in an urban area is primarily motorization, atmospheric dust, fuel combustion products, and - to a lesser extent - fertilizers and plant protection products in green areas [1]. Stormwater and direct surface runoff are a threat to the quality of watercourses, retention tanks, and sediments deposited therein. Also, leaching of some compounds from roofing material may occur [2]. The previous runoff studies in the region of Gdansk, including analytical

*e-mail: nicole.nawrot@pg.edu.pl determination of inorganic and organic pollutants, proved that roof runoff water is contaminated with heavy metals and pesticides [3]. Pollutants are transported along with the surface runoff to the receivers, which are mostly streams and rivers flowing through cities. In many cities, including Gdansk, they are also the receivers of storm water drainage outlets. Although the major pollutant discharged with stormwater runoff is suspended solids (TSS), the runoff also contains other contaminants, like heavy metals (HM), adsorbed on solid particles. Part of the pollutants carried by streams is deposited in the sediments accumulating in retention tanks [4].

There has been a significant increase in the flood risk in Poland over the last decades. Its cause is strong 
anthropopressure manifesting itself in systematic land transformation. In Poland there is a decrease in the share of summer precipitation in annual rainfall, though summer precipitation is characterized by increased intensity and duration compared to similar precipitation in previous decades [5]. Surface sealing causes unfavorable change in the structure of precipitation outflow from the catchment area, and urbanization causes a reduction of underground outflow and an increase of surface runoff [6]. Impervious surfaces in high-density urban areas cover more than $80 \%$ of the surfaces [7]. The effect of precipitation on surface runoff is noticeable much faster in the case of urban catchment areas than the natural area. The consequence of urbanization is the reduction of evaporation, infiltration, retention, and transpiration. Natural water circulation is disturbed [8-9]. A flood wave flowing through a retention tank located on a stream introduces a considerable amount of nutrient, mineral, and organic substances, as well as various types of waste (including municipal waste). It causes increased pollution of the waters and bottom sediments of the tanks. The height of the precipitation that led to the flood in Gdansk on 14-15 July 2017 was $160 \mathrm{~mm}$, and $170 \mathrm{~mm}$ locally in Gdansk Oliwa district. Average monthly rainfall in July in Gdansk for the period 1981 to 2010 was $60 \mathrm{~mm}$, according to the Institute of Meteorology and Water Management (IMGW). The occurrence of precipitation of such intensity caused significant material damage. Flooding extended to the city zoo, roads, residential cellars, and underground garages, and resulted in two deaths. In addition to the losses at the time of the flood, environmental losses and the threat of migration of contaminants are also of importance. The contamination caused by the flooding event in Oliwa Stream was discussed by Matej-Łukowicz and Wojciechowska [10]. However, the changes in the quality of bottom sediments in retention tanks along the stream were also observed as a long-term effect of the flood. The aim of this study is to present the concentrations of heavy metals: zinc $(\mathrm{Zn})$, load $(\mathrm{Pb})$, copper $(\mathrm{Cu})$, and cadmium $(\mathrm{Cd})$ in bottom sediments from 5 retention tanks in Oliwa before the flood (BF) and 8 months after the flood (AF, at a time when the reconstruction of basic parameters of the watercourse was accomplished).

\section{Experimental}

\section{Research Sites}

Oliwa Stream is $9.6 \mathrm{~km}$ long and is the second longest stream in Gdansk, with the largest average flow rate $\mathrm{Q}=158 \mathrm{l} / \mathrm{s}$. Its source is near the S6 express road. The total catchment area is approximately 3,050 ha. The stream inflows directly to the Gulf of Gdansk in Jelitkowo district. In the upper part, the stream flows through the forest area, called the Valley of Joy. Next in the middle part little by little it becomes surrounded by urbanized areas until finally in the lower part the riverbed runs through densely urbanized residential areas, close to traffic arteries. The most important inflow of Oliwa Stream is Rynarzewski Stream, which flows through the city zoological garden. Throughout its length, Oliwa is a receiver for the stormwater drainage system. There are 13 retention tanks on Oliwa, with a total capacity of $70,000 \mathrm{~m}^{3}$ and total area about 13.5 ha. Fig. 1 presents locations and basic information on 5 retention tanks analyzed within this study.

Figs 2 and 3 show Oliwa Stream during the flood. Due to very high rainfall intensity and excessive runoff, some of the retention tanks were damaged and water flooded nearby areas. As a direct effect of the flooding event, a significant increase of pollutant concentrations was observed, and $\mathrm{N}_{\mathrm{NO} 2-}$ increased from

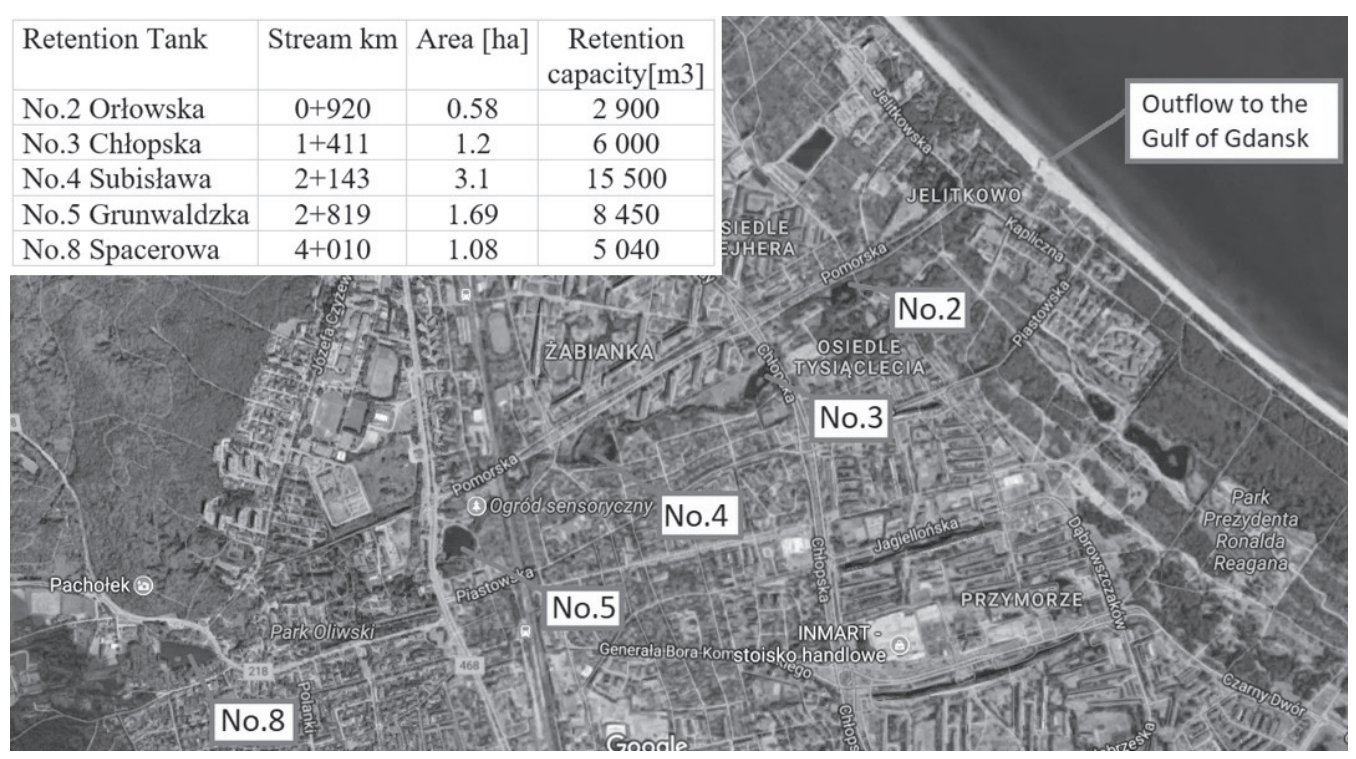

Fig. 1. Locations and retention capacities of analyzed retention tanks on Oliwa Stream. 


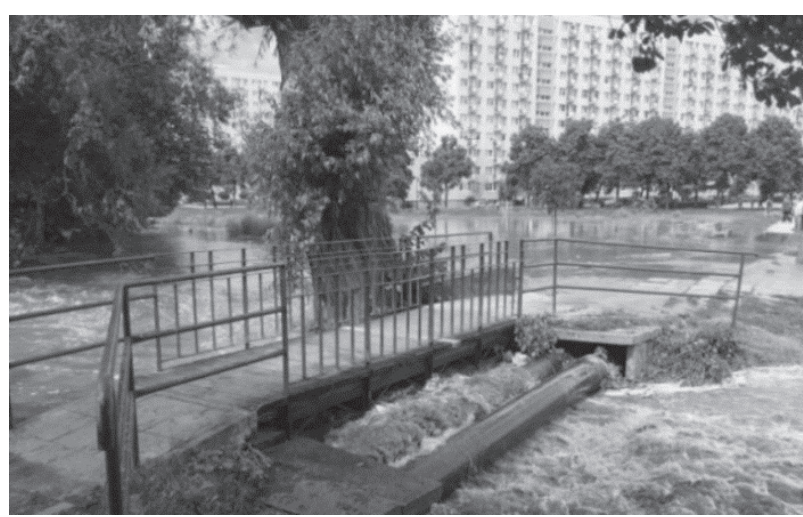

Fig. 2. Tank No. 2 during floods on 14-15 July 2016 [11].

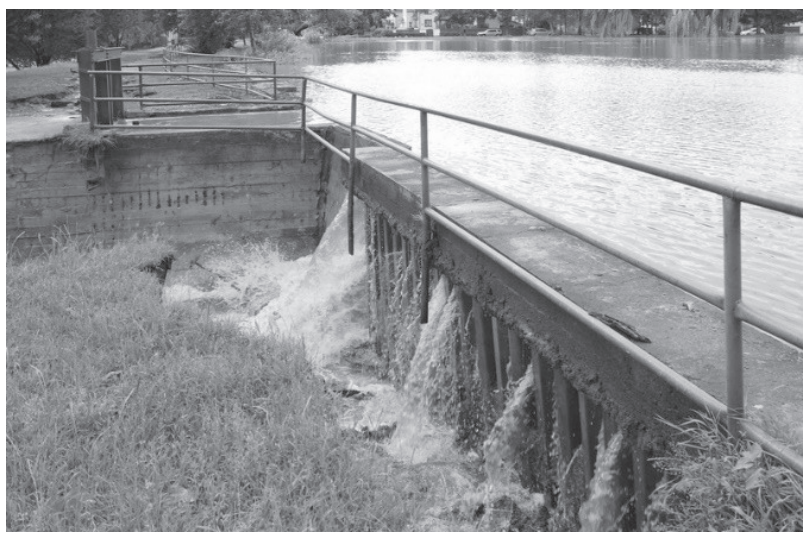

Fig. 3 Tank No.4 during floods on 14-15 July 2016 [11].

0.01 to $0.107 \mathrm{mg} / \mathrm{dm}^{3} \mathrm{AF}, \mathrm{N}_{\mathrm{NO} 3-}$ increased from 0.02 to $2.29 \mathrm{mg} / \mathrm{dm}^{3} \mathrm{AF}$, and $\mathrm{N}_{\mathrm{NH}_{4}+}$ increased from 0.04 to $0.50 \mathrm{mg} / \mathrm{dm}^{3} \mathrm{AF}[10]$. As a consequence, the beach and bathing place in Jelitkowo, near the mouth of Oliwa had to be closed a few days after the urban flood.

\section{Sampling}

Samples of sediment from 5 retention tanks were collected in April 2016 and March 2017 (3 series of samples in each sampling event). The samples were collected from the following tanks on Oliwa Stream:
No. 2 (Orłowska), No. 3 (Chłopska), No. 4 (Subisława), No. 5 (Grunwaldzka), and No. 8 (Spacerowa) (Fig. 1). The samples were taken at 2 or 3 points of each tank - near the inflow (A) and outflow (B), and also (if possible) in the middle part (S). Sludge samples were taken with a plastic sampler. Samples were placed in string bags and delivered to the laboratory within 4 hours of extraction.

\section{Mineralization}

The samples were homogenized, transferred to Petri dishes and dried for 24 hours in Christ lyophilizer. Dried sediments were homogenized in a mortar and sealed in boxes. The next stage of analysis was sediment mineralization with $\mathrm{HClO}_{4}, \mathrm{HF}$, and $\mathrm{HCl}$ in teflon bombs. Half a gram substrate sediment sample was used for mineralization. Then the mineralized sediment samples were dissolved in $10 \mathrm{ml} 0.1 \mathrm{M} \mathrm{HNO}_{3}$ and placed in tubes. Dilutions $\mathrm{x} 10$, x100, and $\mathrm{x} 1,000$ were also analyzed using atomic absorption spectrometry (AAS). Cadmium analysis was done with inductively coupled plasma mass spectrometry (ICP-MS) due to the wider measure of detection limit ranges.

\section{Analysis of Sediments Samples}

Determining metals concentrations in the sediment samples from retention tanks on Oliwa after mineralization were carried out using the AAS SHIMADZU 6800 atomic absorption technique with the flame technique and the background correction (deuterium lamp). Quality control was assured by running 'blanks' according to the same procedure. The precision was in the range $3-5 \%$. An atomic absorption spectrophotometer (AAS) measured the concentrations of $\mathrm{Zn}, \mathrm{Pb}, \mathrm{Cu}$, and $\mathrm{Cd}$ in sediment samples. Before each measurement the lamp intended for the metal annealed for 2 hours and flame cleanliness was checked. A standard curve was made each time before the examination of each metal. The tubes were placed in the automatic feeder. The measurements were carried out in 3 replications. All control of the instrument was performed using a computer program that printed the results of absorbance and concentration in $\mu \mathrm{g} / \mathrm{ml}$. The results of the metal content were finally converted into $\mathrm{mg} / \mathrm{kg}$ d.m. In the

Table 1. Classification of sediments based on HM concentration (mg/kg d.m.) according to LAWA [12].

\begin{tabular}{|c|c|c|c|c|c|c|c|}
\hline \multirow{2}{*}{ Metal } & \multicolumn{9}{|c|}{ Purity class } \\
\cline { 2 - 8 } & I & I - II & II* & II - III & III & III - IV & IV \\
\hline Zinc $(\mathrm{Zn})$ & $\leq 100$ & $\leq 150$ & $\leq 200$ & $\leq 400$ & $\leq 800$ & $\leq 1600$ & $>1600$ \\
\hline Lead $(\mathrm{Pb})$ & $\leq 25$ & $\leq 50$ & $\leq 100$ & $\leq 200$ & $\leq 400$ & $\leq 800$ & $>800$ \\
\hline Copper $(\mathrm{Cu})$ & $\leq 20$ & $\leq 40$ & $\leq 60$ & $\leq 120$ & $\leq 240$ & $\leq 480$ & $>480$ \\
\hline Cadmium $(\mathrm{Cd})$ & $\leq 0.3$ & $\leq 0.6$ & $\leq 1.2$ & $\leq 2.4$ & $\leq 4.8$ & $\leq 9.6$ & $>9.6$ \\
\hline
\end{tabular}

Explanations: Class I - uncontaminated sediment, without anthropogenic interference; Class I-II - sediments unpolluted or with very small anthropogenic interference; Class II - corresponds to moderately polluted sediments; Class II-III - moderate to significant contamination of sediments; Class III - significant pollution; Class III-IV - very strong pollution; Class IV - ultimate pollution 
Table 2. Classification of sediments based on HM concentration (mg/kg d.m.) according to SQG [13].

\begin{tabular}{|c|c|c|}
\hline \multirow{2}{*}{ Metal } & \multicolumn{2}{|c|}{ Sediment Quality Guidelines } \\
\cline { 2 - 3 } & TEC* & PEC$^{*}$ \\
\hline Zinc $(\mathrm{Zn})$ & 121.0 & 459.0 \\
\hline Lead $(\mathrm{Pb})$ & 35.8 & 128.0 \\
\hline Copper $(\mathrm{Cu})$ & 31.6 & 149.0 \\
\hline Cadmium $(\mathrm{Cd})$ & 0.99 & 4.98 \\
\hline
\end{tabular}

Explanations: *Consensus-based TEC and PEC - Criteria provided by MacDonald et al. (rok) based on comparisons of each type of SQG (sediment toxicity is observed only rarely below TEC and frequently observed above the PEC)

case of cadmium, analysis was carried out using an ELAN 9000 Perkin Elmer inductively coupled plasma mass spectrometer (ICP-MS).

\section{Evaluating Sediment Pollution with HM}

In order to asses contamination of sediments with HM the measurement results were compared to the LAWA classification [12], which divides the TSS, water, and bottom sediments into 7 classes, with different HM concentrations. The boundary values for each class are shown in Table 1. Comparative value is the average content of HM expressed in $\mathrm{mg} / \mathrm{kg}$.

The results were also compared to the sediment quality guidelines (SQG), which determine two pollution levels: threshold effects concentration (TEC) and probable effects concentration (PEC) [13]. The TEC indicator specifies a threshold that defines the absence of sediment toxicity for a freshwater ecosystem, while the PEC indicator provides an accurate basis for predicting sediment toxicity. The values of TEC and PEC are shown in Table 2.

\section{Results and Discussion}

The results of HM concentrations in the sediments from retention tanks on Oliwa Stream are shown at Figs 4-6. The HM concentrations differed significantly between research series conducted $\mathrm{BF}$ and AF. There were no obvious trends in the distribution of HM along Oliwa Stream, but for most of the observed results the HM seemed to be move to the tanks located downstream as a result of the flood.

Concentrations of $\mathrm{Zn}$ (Fig. 4) before the flood incident were between $27.4 \mathrm{mg} / \mathrm{kg}$ d.m. in No. 3 tank (inflow) to $129.9 \mathrm{mg} / \mathrm{kg}$ d.m. in No. 8 tank (outflow); compared to the LAWA classification this means that sediments were not contaminated. In relation to SQG, sediments were not toxic for aquatic organisms. The increase in
$\mathrm{Zn}$ content in bottom sediments AF occurred for tank Nos. 2, 4, and 5 at the inflow and tank Nos. 3, 4, and 5 in the middle part and at the outflow. The average content of $\mathrm{Zn}$ in sediments from the retention tanks is approximately $125 \mathrm{mg} / \mathrm{kg}$ d.m. In two cases - tank Nos. 4 (point S) and 5 (point B) - the boundary value of the II class of purity according to LAWA (more than $200 \mathrm{mg} / \mathrm{kg}$ d.m.) was exceeded. The increase in $\mathrm{Zn}$ content AF could be caused by intensive surface runoff (especially from streets with intensive traffic), which was stopped and deposited in the bottom sediments after the flood wave. Similar results were obtained for $\mathrm{Pb}$ (Fig. 5). The content range for $\mathrm{Pb} \mathrm{BF}$ was between $8.5 \mathrm{mg} / \mathrm{kg}$ d.m. to $50.2 \mathrm{mg} / \mathrm{kg}$ d.m. - which refers to uncontaminated sediments according to LAWA classification. AF the $\mathrm{Pb}$ content rose at the same points as $\mathrm{Zn}$. This supports the thesis that in contaminated sediments $\mathrm{Zn}$ occurs often together with $\mathrm{Pb}$ [14]. At inlet to tank No. 8 the $\mathrm{Pb}$ content was $160.6 \mathrm{mg} / \mathrm{kg}$ d.m., exceeding the second class of purity (LAWA). Additionally, the limit for PEC was exceeded in this case.

The $\mathrm{Cu}$ content (Fig. 5) in bottom sediments in April 2016 was from $3.0 \mathrm{mg} / \mathrm{kg}$ d.m. (No. 8 - inflow) to $88.8 \mathrm{mg} / \mathrm{kg}$ d.m. (No. 5 - inflow), and only in the latter sampling point was the class II of purity (according to LAWA). After the flood incident the sediment contamination with $\mathrm{Cu}$ increased to $29.5 \mathrm{mg} / \mathrm{kg}$ d.m. in retention tank No. 5 (inflow), and the remarkable level of $1,114.3 \mathrm{mg} / \mathrm{kg}$ d.m. was observed at the inflow to tank No. 2. In this case the PCB indicator was exceeded 7.5 times. Such a significant increase in $\mathrm{Cu}$ concentration can be attributed to the intense surface runoff of areas located near the stream, including numerous garden plots (copper is widely used in the production of insecticides and fungicides). In addition, in the Oliwa District many roofs are made of copper. It is worth noting that $\mathrm{BF}$ the highest concentrations of $\mathrm{Cu}$ were observed in tank No. 5 located in the center of Oliwa District, where copper roofs are present, while $\mathrm{AF}$ a record $\mathrm{Cu}$ concentration was measured in tank No. 2 located right before the inflow to the Gulf of Gdansk. Also, the $\mathrm{Cu}$ concentrations

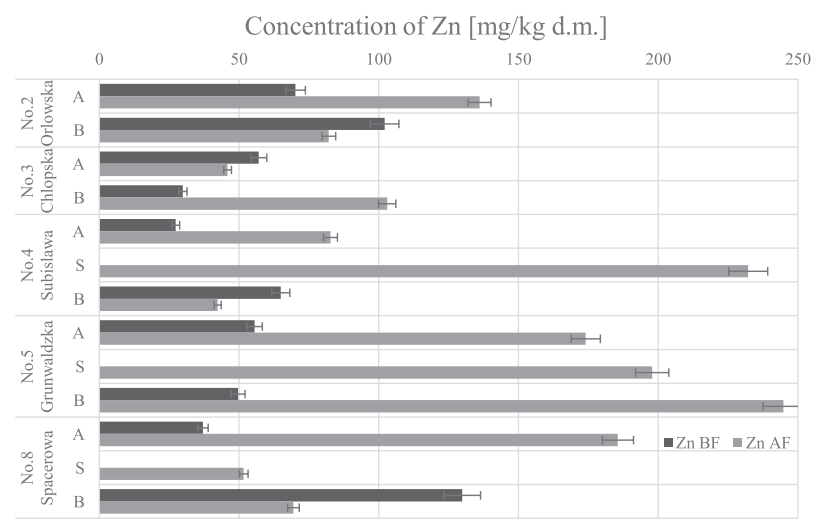

Fig. 4. Average concentrations of $\mathrm{Zn}$ in bottom sediments of retention tanks on Oliwa Stream before flood (BF) and after flood (AF). 


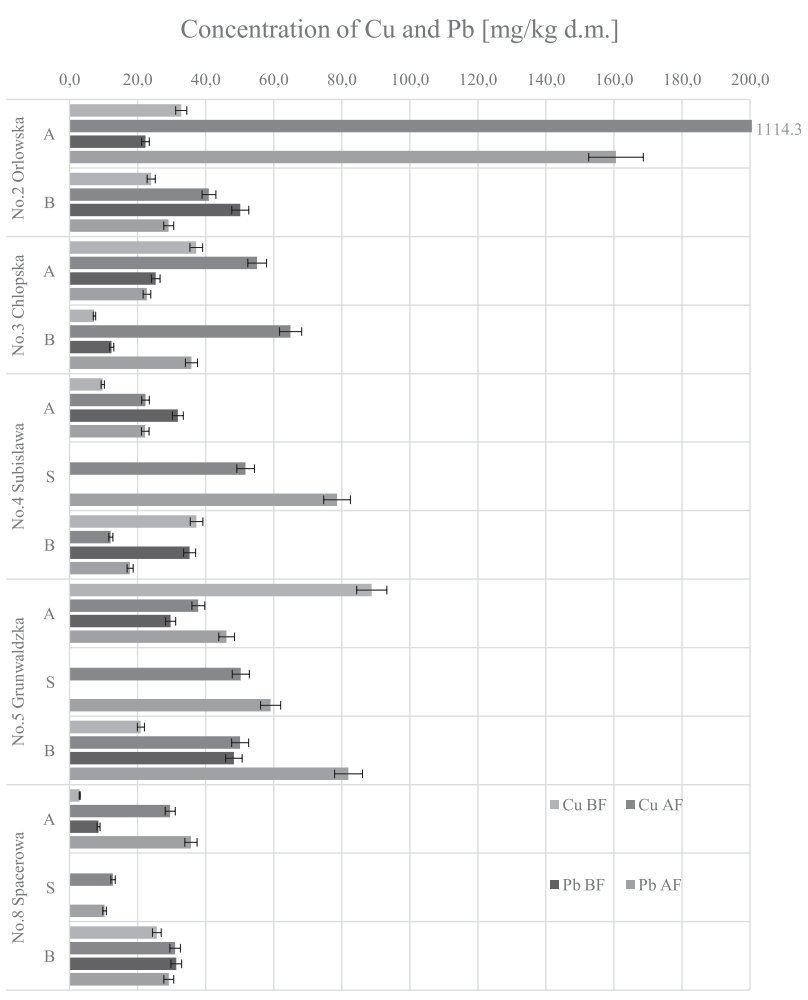

Fig. 5. Average concentrations of $\mathrm{Cu}$ and $\mathrm{Pb}$ in bottom sediments of retention tanks on Oliwa Stream before flood (BF) and after flood (AF).

in tank No. 3 were considerably higher AF than BF. This suggests that transport of $\mathrm{Cu}$ to the tanks located downstream occurred and could be a result of the flood, which caused washing out and movement of sediments deposited in the tanks located in the middle part of the stream. Also, during the flood, the dam on retention tank No. 4 was damaged and the sediments from this tank were washed away by stream water. $\mathrm{Cu}$ is often bound with organic fraction, which probably settled in the downstream tank Nos. 3 and 2. A high concentration of $\mathrm{Cu}$ in tank No. 2 located right near the outflow to the Gulf of Gdansk creates a real risk that the metal could finally end up in the sea in case of another flood episode causing disturbance and movement of deposited sediments.

Concentrations of $\mathrm{Cd} \mathrm{BF}$ and $\mathrm{AF}$ did not exceed the value for I-II class (LAWA), indicating that sediments were unpolluted or with very small anthropogenic interference. Also, the threshold effect concentration was not exceeded. The Cd concentrations in sediments are shown in Fig. 6. Significant sources of $\mathrm{Cd}$ in the environment are fertilizers (e.g., superphosphates), which are contaminated with this metal from 10 to $100 \mathrm{mg} / \mathrm{kg}$ [15]. Comparing the $\mathrm{Cd}$ content in bottom sediments $\mathrm{BF}$ and $\mathrm{AF}$ shows that in most retention tanks $\mathrm{Cd}$ concentrations were higher AF than BF. However, in tank Nos. 2 and 4 (point B - outflow), Cd concentrations decreased AF. The smallest differences between BF and AF concentrations were noted in the case of tank No. 8 (located upstream). The highest AF Cd concentrations were measured in tank Nos. 5 and 4 located in the middle

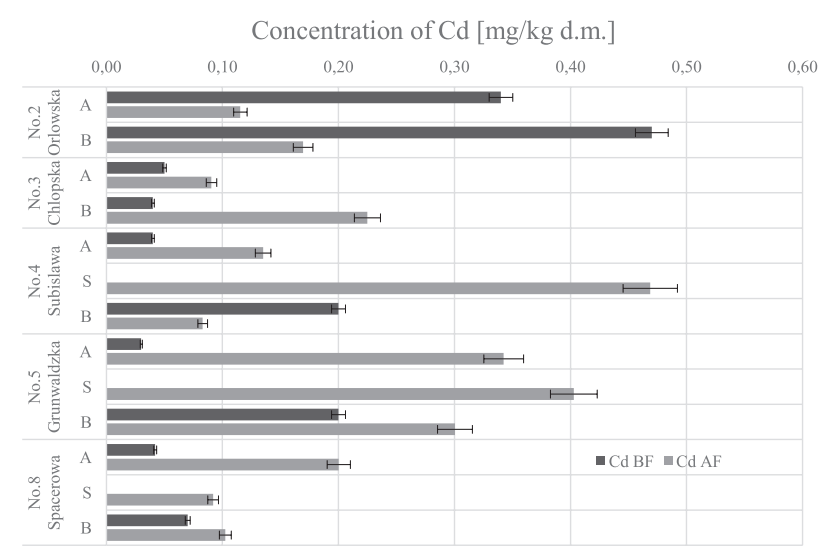

Fig. 6. Average concentrations of $\mathrm{Cd}$ in bottom sediments of retention tanks on Oliwa Stream before flood $(\mathrm{BF})$ and after flood (AF).

part of the stream, which was seriously affected by the flood. The highest BF Cd concentrations were measured in sediments of tank No. 2. This raises a question of whether Cd from tank No. 2 could be washed away from the sediments and moved to the Gulf of Gdansk. Cd is known for its ability to accumulate and quickly migrate in the trophic chain of soil-plant-man [16], which makes this question highly significant.

\section{Conclusions}

1. Concentrations of all analyzed metals $(\mathrm{Zn}, \mathrm{Pb}, \mathrm{Cu}$, $\mathrm{Cd})$ were generally higher in samples taken $\mathrm{AF}$ than BF, with a few exceptions. The concentrations $\mathrm{AF}$ were respectively higher than $\mathrm{BF}$ for zinc (1.9 to 5.0 times), copper (1.2 to 33.9 times), lead (1.5 to 7.2 times), and cadmium (1.4 to 11.4 times). Only for a few sampling points were the concentrations of analyzed heavy metals lower AF than BF.

2. Taking into account the same season of bottom sediment sampling (April 2016 and March 2017), the differences in measured HM concentrations are significant. The difference is mainly in the value of zinc concentration in retention tank No.5 - BF the concentrations were: $55.5 \mathrm{mg} / \mathrm{kg}$ (A) and $49.6 \mathrm{mg} / \mathrm{kg}$ (B), while AF: $174.1 \mathrm{mg} / \mathrm{kg}$ and $244.8 \mathrm{mg} / \mathrm{kg}$, respectively. Since the type of land development was unchanged and sources of pollution were similar (early spring snow melts, car traffic, etc.) in both sampling periods, the change of bottom sediment quality probably resulted from the urban flood of July 2016, when rapid washing away of deposited bottom sediments occurred.

3. The concentrations of $\mathrm{Zn}, \mathrm{Pb}$, and $\mathrm{Cd}$ in the analyzed sediments showed no or low levels of contamination according to the LAWA classification. $\mathrm{Cu}$ concentrations in sediments from several sampling points showed medium to high levels of pollution. $\mathrm{Cu}$ concentrations before flood were highest in tank No. $5(\mathrm{~A}-88.8 \mathrm{mg} / \mathrm{kg})$ located in the centre of old 
Oliwa District with numerous copper roofs, while after flood the outstandingly high concentrations of $\mathrm{Cu}$ were measured in downstream tank Nos. 3 $(\mathrm{B}-64.9 \mathrm{mg} / \mathrm{kg})$ and $2(\mathrm{~A}-1114.3 \mathrm{mg} / \mathrm{kg})$, suggesting that $\mathrm{Cu}$ was transported downstream as a result of washing out of the sediments deposited in the middle run of Oliwa Stream by an extremely high flow.

\section{Acknowledgements}

The work was completed under a GRAM grant, awarded in a competitive procedure by the Dean of the Faculty of Civil and Environmental Engineering, Gdansk University of Technology. The grants are funded from science funds as specified in Journal of Laws No. 96, heading 615, as amended.

\section{Conflict of Interest}

The authors declare no conflict of interest.

\section{References}

1. ANGRILLA S., PETIT-BOIXA A., MORALES-PINZÓNB T., JOSAC A., RIERADEVALLA J., GABARELLA X. Urban rainwater runoff quantity and quality - A potential endogenous resource in cities?, Journal of Environmental Management 189, 14, 2017.

2. NAWROT N., WOJCIECHOWSKA E. Assessment of trace metals leaching during rainfall events from building rooftops with different types of coverage - case study. Journal of Ecological Engineering, 19 (3), 45, 2018.

3. POLKOWSKA Ż., GÓRECKI T., NAMIEŚNIK J. Quality of roof runoff waters from an urban region (Gdańsk, Poland). Chemosphere 49, 1275, 2002

4. OBARSKA-PEMPKOWIAK H., GAJEWSKA M., WOJCIECHOWSKA E. Application of vertical flow constructed wetlands for highly contaminated wastewater treatment: preliminary results. Water and Nutrient Management in Natural and Contstructed Wetlands J.Vymazal (Ed), Springer Science+Busines Media B.V. chapter 4, 37, 2010.

5. KRÓLIKOWSKA J., KRÓLIKOWSKI A. Wody opadowe. Odprowadzanie, zagospodarowanie, podczyszczanie i wykorzystanie, eng. Rainwater. Discharge, management, pre-treatment and use, Seidel-Przywecki, Warszawa, 2012.
6. ROMANOWICZ R.J., NACHLIK E., JANUCHTASZOSTAK A., STARKEL L., KUNDZEWICZ Z.W., BYCZKOWSKI A., KOWALCZAK P., ŻELAZIŃSKI J., RADCZUK L., KOWALIK P., SZAMAŁEK K. Zagrożenia związane z nadmiarem wody, eng. Threats related to water excess, Nauka 1/2014, 123-148, 2014.

7. KAYE J., GROFFMAN P., GRIMM N., BAKER L., POUYAT R. A distinct urban biogeochemistry? Trends in Ecology and Evolution 21, 192, 2006.

8. WOJCIECHOWSKA E., RACKIEWICZ A., NAWROT N., MATEJ-ŁUKOWICZ K., OBARSKA-PEMPKOWIAK $\mathrm{H}$. Investigations of heavy metals distribution in bottom sediments from retention tanks in the urbanized watershed. Rocznik Ochrona Środowiska, Annual Set The Environment Protection) 19, 572, 2017 [In Polish].

9. WEINEROWSKA-BORDS K. Wpływ uproszczeń na obliczanie spływu deszczowego w zlewni zurbanizowanej, eng. Impact of simplifications on the calculation of rainfall in an urbanized catchment, Gdansk University of Technology Publishing House, Gdańsk, 2010.

10. MATEJ-ŁUKOWICZ K., WOJCIECHOWSKA E. Contamination of water in Oliwski Stream after the flood in 2016. E3S Web Conf. 17, 2017 Proc. of $9^{\text {th }}$ Conference on Interdisciplinary Problems in Environmental Protection and Engineering EKO-DOK 2017.

11. https://www.trojmiasto.pl/wiadomosci/Bilans-ulewy-wTrojmiescie-n103662.html (accessed on 15 $5^{\text {th }}$ July 2016) .

12. LAWA-Arbeitskreis „Zielvorgaben” in Zusammenarbeitmit LAWA-Arbeitskreis „Qualitative Hydrologie der Fließgewässer”, Beurteilung der Wasserbeschaffenheit von Fließgewässern in der Bundesrepublik Deutschland - Chemische Gewässergüte klassifikation, eng. LAWA Chemical waters classification, Berlin, 1998.

13. MACDONALD D.D., INGERSOLL C.G., BERGER T.A. Development and evaluation of consensus-based Sediment Quality Guidelines for freshwater ecosystems, Archives of Environmental Contamination and Toxicology 39, 20, Springer Verlag, New York Inc, 2000.

14. ZWONITZER J.C., PIERZYNSKI G.M., HETTIARACHCHI G.M. Effects of phosphorus addition on lead, cadmium, and zinc bioavailabilities in a metalcontaminated soil. Water, Air, and Soil Pollution, 143, 193, 2003.

15. CZECZOT H., MAJEWSKA M. Kadm - zagrożenie i skutki zdrowotne, eng. Cadmium - threat and health effects, Toksykologia, 66 (4), 2010.

16. KHAN M.A., KHAN S., KHAN A., ALAM M., Soil contamination with cadmium, consequences and remediation using organic amendments, Science of the Total Environment 301-302, 2017. 